\title{
LA PERVERSIÓN \\ DE LA DEMOCRACIA: \\ UN FLACO FAVOR A \\ MÉXICO
}

Venustiano Reyes*

Nuestro sistema democrático tiene dos fallas legales que lo pervierten y distorsionan: una es el principio de elección por mayoría relativa; la otra es la asignación de diputados y senadores mediante un obsoleto principio de representación proporcional. La primera de estas 'fallas' permitió al PRI eternizarse en el poder por siete décadas, con los funestos resultados que todos reconocen, y permite ahora a los partidos políticos hacer de las entidades federativas que gobiernan, bastiones inexpugnables. Pensemos en la relación existente entre el PRD y el Distrito Federal, el PRI y el Estado de México, o el PAN y Guanajuato. Por otro lado, los partidos grandes están sobre-representados (en detrimento de los pequeños, a quienes supuestamente el principio de representación proporcional intenta proteger), pues además de los cargos de elección popular que mediocremente ganan, obtienen un número seguro de representantes en el Congreso de la Unión y en todos los congresos locales. La verdadera democracia es incompatible con estos principios de elección.

En efecto, la 'mayoría relativa' es en el fondo una 'minoría absoluta', en el sentido peyorativo que el argot técnico da al término 'absoluto'. En las elecciones del 2 de julio lo vimos con toda claridad: ningún candidato a la presidencia se acercó al 50\% de los votos. Así las

* Escritor. 
cosas, el candidato ganador fue electo por una minoría, y en diciembre se convertirá en el presidente constitucional de los Estados Unidos Mexicanos, según el rancio título que le confiere nuestra constitución. Pero, ¿de qué legitimidad dispone un presidente que sólo contó con alrededor del $35 \%$ de los votos ciudadanos? Un porcentaje que oscilaría alrededor del $65 \%$ de los votantes no lo querría a la cabeza del gobierno federal. En consecuencia, la minoría se ha impuesto sobre la mayoría. Un presidente así electo no puede tener origen democrático; por el contrario, un presidente así electo es un presidente 'impuesto'. Bien lo señalaba Locke (de quien todos tenemos algo que aprender): una efectiva democracia requiere coincidencia entre la 'mayoría' y la 'fuerza mayor'. En toda sociedad interactúan diversas fuerzas, y es evidente que no todas tienen el mismo peso. El peligro es que si la 'fuerza mayor' no se sustenta en, o no es avalada por, la 'mayoría', tendríamos como resultado la tiranía de una minoría. Y no estamos hablando únicamente de la elección del presidente, sino de todos los cargos de elección popular que se eligen bajo este principio. Es improbable que las disposiciones electorales que facilitan estas mezquindades democráticas sean corregidas en el corto plazo; nadie desea perder su rebanada de pastel. Si no es la presidencia, al menos aspiran a un pedazo gordo del Congreso. El caso del PRI fue muy claro: sabía que la elección presidencial estaba perdida, de modo que lo único que le quedó fue rescatar una tajada de curules.

John Stuart Mill, señaló con precisión que si bien una minoría puede convertir sus intereses en 'fuerza mayor', también la 'mayoría' ostentando la 'fuerza mayor' -lo cual sería en principio deseable- podría atropellar a alguna o a algunas minorías, como de hecho sucedió en los Estados Unidos con la población negra, o en la Alemania nazi con los judíos, por mencionar dos ejemplos. Y es que tampoco debe entenderse la democracia como 'gobierno de la mayoría'. En todo caso podemos decir que la democracia implica, entre otras cosas, representación y participación de todas las fuerzas políticas en la conformación de la voluntad estatal. El escenario natural para esto son las asambleas populares. Para alcanzar tal objetivo, Mill propuso 
el sistema de representación proporcional. En tal sistema, los votos se dividen en útiles e inútiles. Los primeros son los suficientes para que un determinado candidato asegure el cargo, suponiendo no una elección de mayoría relativa, sino una de mayoría absoluta. Logrado esto, el siguiente voto ya no lo beneficia, y por eso se asigna a otro u otros candidatos. Pero en nuestro sistema, los votos que ya no benefician a un candidato de mayoría relativa (lo único que requiere es obtener más votos que sus contrincantes) benefician a su partido - a pesar de las barreras legales que impone el artículo 54 constitucional-, de tal suerte que esas 'calorías extra' surten su peor efecto: partidos gordos, lerdos, mezquinos y, en algunos casos, pusilánimes. Por desgracia, también resulta improbable que las disposiciones legales que fomentan semejante vicio sean corregidas en el corto plazo.

La implementación de la segunda vuelta asegura que cualquier candidato a un cargo de elección popular gane con el respaldo de por lo menos el $51 \%$ de los votos, lo que de inmediato garantiza legitimidad y brinda mejores condiciones de gobernabilidad. Es caro, sí. De cualquier forma nuestra imperfecta democracia es una de las más caras del mundo. En vez de asignar a los partidos políticos recursos escandalosos que serán derrochados en spots de radio y televisión (las elecciones pueden ser para las televisoras incluso más lucrativas que las Olimpiadas y el Mundial de Fútbol), y que generarán toneladas de basura electoral, bien podrían asignarse para cubrir una segunda vuelta en caso necesario. Por otro lado, no es recomendable extirpar por completo el principio de representación proporcional. Hay que corregirlo, de manera que los votos inútiles, esas 'calorías extra', no sigan engordando a partidos ya de por sí pingües, sino que beneficien verdaderamente a las fuerzas minoritarias. El equilibrio político que todos anhelamos están aún lejos, pero es necesario dar los primeros pasos. Lo que sí queda muy claro es que los partidos y los candidatos 'gordos' le están haciendo un 'flaco' favor a México. 
CITAM Derechos Reservados.

La reproducción total o parcial de este artículo se podrá hacer si el ITAM otorga la autorización previamente por escrito. 